\title{
A new nature reserve in the Eastern Arc mountains, Tanzania
}

\author{
Jon C. Lovett and David C. Moyer
}

\author{
A small area of forest on Luisenga tea estate has been declared a nature reserve \\ by Brooke Bond Tanzania Limited. Luisenga is at the southern end of the \\ endemic-rich Eastern Arc mountains of Tanzania and contains a number of \\ plant and animal species of restricted distribution and conservation \\ importance.
}

Moist forests of eastern Tanzania and southeast Kenya are of considerable biological interest (for reviews see Stuart and Jensen, 1981; Lovett, 1988a; Polhill, 1989) with plant species endemism at 25-30 per cent (Lovett, 1988b). Forests associated with the disjunct arc of ancient crystalline mountains from the Teita Hills in south-east Kenya to the Uzungwa mountains of southern Tanzania, under the direct climatic influence of the Indian Ocean, are called the Eastern Arc forests (Lovett, 1985; Lovett, 1990). Most of these forests are in forest reserves and have been extensively exploited for timber, either by pitsawing or mechanized logging. Further disturbance from stock grazing, removal of regenerating trees for building poles and other forest products, and encroachment for agriculture continue in many reserves. Very few areas are strictly protected, exceptions being the 450-ha University of Dar es Salaam forest reserve at Mazumbai in the West Usambara mountains (Redhead, 1981) and the 450-ha forest patch on Malundwe Hill in Mikumi National Park (Lovett and Norton, 1989). A 100,000-ha national park in the northern Uzungwa mountains has been proposed (Rodgers and Homewood, 1982), which would include substantial areas of forest and should be gazetted soon.

Although some of the Eastern Arc forests still cover extensive areas, they are increasingly fragmented or disturbed. While it is desirable to conserve as large an area of forest as possible, small forest patches separated by grassland, cultivation and plantations of exot ic trees are also important. Such patches oftenharbour species of restricted distribution or may act as stepping stones in migration and dispersal of forest-dependent organisms. Inclusion of these areas in a system of nature reserves is probably the best method of protecting them. A conservation category between forest reserve and national park, which would cover the concept of nature reserve, does not officially exist in Tanzania at present, but has been successfully implemented in neighbouring countries.

The forest along the Luisenga stream in the southern Uzungwa mountains of Tanzania demonstrates the importance of forest fragments because it contains many species that are rare or restricted in distribution (Lovett, 1989). Luisenga stream is on land leased by Brooke Bond Tanzania Limited and the recent declaration of this area as a nature reserve by M. Keeley and C. Congdon of Brooke Bond Tanzania is an example of far-sighted management by a commercial company, which is to be warmly welcomed.

\section{Description of Luisenga Stream Nature Reserve}

Luisenga stream on the Brooke Bond Tanzania tea estate, Mufindi District, Iringa Region, Tanzania $\left(08^{\circ} 36^{\prime} \mathrm{S} 35^{\circ} 18^{\prime} \mathrm{E}\right)$ is on the edge of the southern Uzungwa escarpment (Figure 1). The nature reserve extends $100 \mathrm{~m}$ either side of the stream for $1.5 \mathrm{~km}$ and covers 30 ha. Rising at Luisenga Dam at $1830 \mathrm{~m}$, the stream passes 
through a forested valley with an irregular canopy about $10 \mathrm{~m}$ tall. During the dry season it disappears amongst rocks at $1700 \mathrm{~m}$, emerging several hundred metres later to fall down the escarpment. Only the upper part of the stream is on the Brooke Bond estate, the lower stream is in the Mufindi Scarp Forest Reserve. Luisenga Dam was built in the late 1930s for small scale electricity production, although it never functioned because the turbines and generators were sunk while being shipped at the outbreak of World War II. The dam flooded a swampy glade that was formerly used for grazing, a practice that gave rise to the name Luisenga, or 'place of the cows' in the local Kihehe language.

Over the last 5 years Luisenga stream received an average of $2032 \mathrm{~mm}$ of rain a year, with a maximum of $2478 \mathrm{~mm}$ (in 1989) and a minimum of $1790 \mathrm{~mm}$ (in 1987). There is a single rainy season, peaking in April and ending in June, with a 26-week dry season from the first week in June to the fourth week in November. Mean monthly temperature varies from $17.5^{\circ} \mathrm{C}$ in January to $13^{\circ} \mathrm{C}$ in June. During the dry season mists are common and there are occasional frosts in July and August.

Luisenga stream has been stocked with rainbow trout and the Mufindi Rod and Gun Club maintain a path along the edge of the stream. There is a fishing lodge on the reservoir, which can be rented overnight or for short visits with advance notice (contact Mufindi Rod and Gun Club, PO Box 40, Mufindi, Tanzania).

The forests at Luisenga are well known botanically, but may still contain new or rare species of plants. The vegetation can be divided into closed canopy forest and open scrubby thicket. The closed canopy forest is upper montane forest with a well developed shrub layer giving way to scrubby thicket on infertile soils over clay and stone deposits. The avi

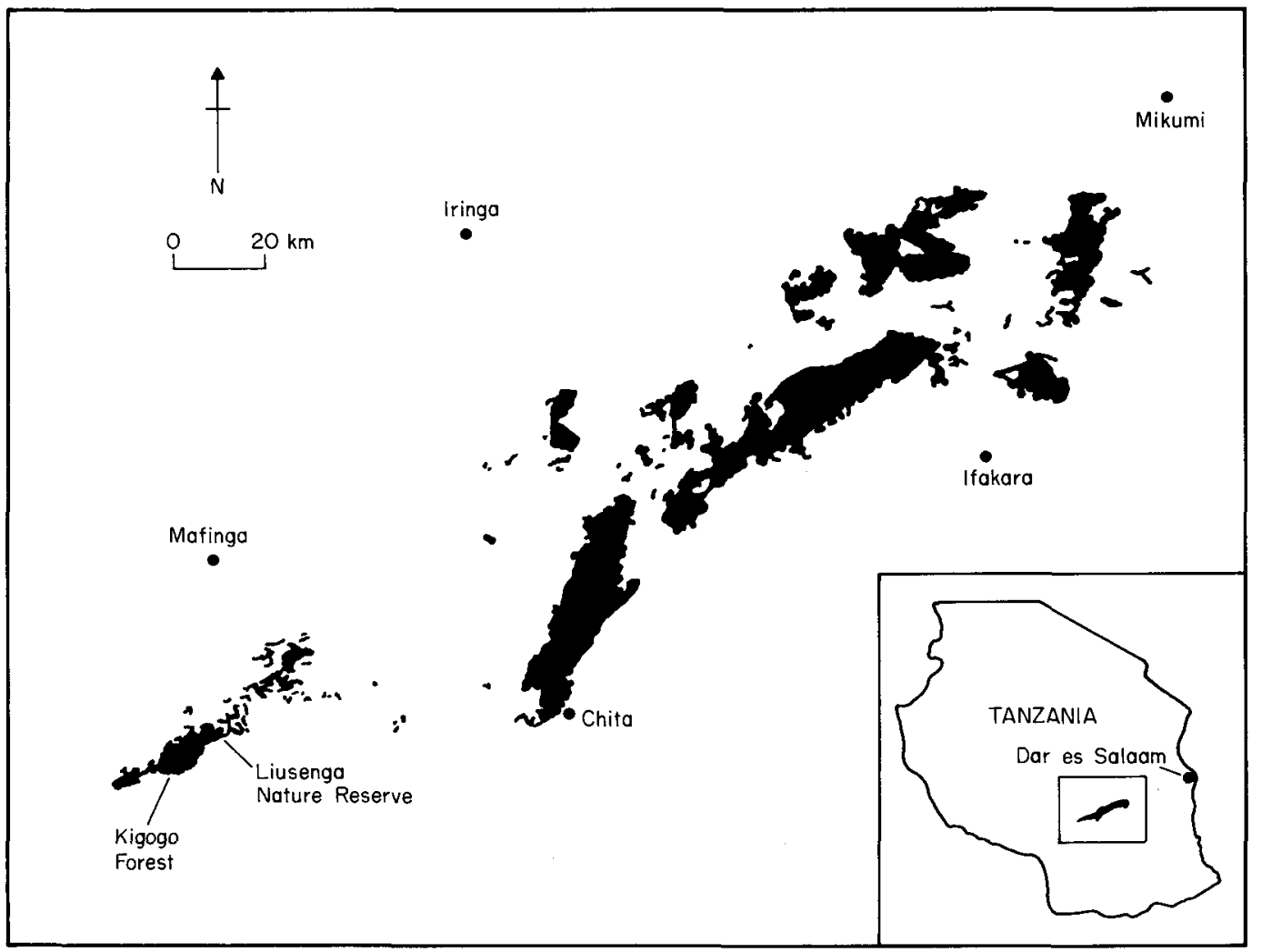

Figure 1. Map of the Uzungwa Mountains, Tanzania, showing forested areas in black. 
fauna and butterflies are also well known and there have been a number of bird-ringing studies.

\section{Biological importance}

Luisenga forest is surprisingly diverse for such a small area and contains a number of species of special conservation concern. The tree Trichocladus goeztei grows on the forest edge. It is rare where it occurs and is known only from the Uzungwa and Rungwe mountains in Tanzania, and northern Malawi. The climbing bamboo Hickelia sp. aff. madagascariensis, which scrambles in open areas along the stream, is known only from Luisenga and Lisitu forest in the Livingstone mountains, while the epiphytic orchid Stolzia christopheri is known only from Luisenga and adjacent Kigogo forests. An as yet undescribed species of Eugenia occurs in the lower part of Luisenga, and has not been recorded elsewhere. Also along the lower stream, on deeply shaded banks, is a possible new species of Scadoxus, which has also been recorded from Dabaga and Kigogo forests of the Uzungwa mountains. A record of distributional interest is the northern-most occurrence of the tree Schefflera umbellifera.

Around 70 species of forest bird have so far been recorded in Luisenga Stream Nature Reserve. Many of these are species with restricted distributions, most of which have been classified as 'rare' or 'candidate threatened species' in the ICBP/IUCN Red Data Book (Collar and Stuart, 1985). Some of the most interesting species include the following: black boubou Laniarius fuelleborni; oliveflanked robin-chat Cossypha anomala; Iringa ground robin Sheppardia loweii; white-chested alethe Alethe fuelleborni; spot-throat Modulatrix stictigula; red-capped forest warbler Orthotomus metopias; Kenrick's starling Peoptera kenrickii and Njombe thick-billed seed-eater Serinus burtoni melanochorus. Several species of birds, including squaretailed drongo Dicrurus ludwigii, Sharpe's akalat Sheppardia sharpei, and yellow-streaked greenbull Phyllastrephus flavostriatus, are apparently absent from Luisenga and the nearby Kigogo forest for unknown reasons. These species occur in other parts of the Uzungwa mountains in habitats with similar structural complexity, altitudinal range and rainfall regimes.

Luisenga is the type locality for the butterfly Chondrolepis similis, which has otherwise only been recorded at nearby Lulanda and Lupeme. It is also the type locality for Chondrolepis obscurior and Meltisella congdoni, and a habitat for the rare swallowtail Papilio thuraui.

Harvey's red duiker Cephalophus natalensis harveyi, suni antelope Nesotragus moschatus, clawless otter Aonyx capensis, Sykes and vervet monkeys, Cercopithecus mitis and C. aethiops, are also found in the Luisenga reserve.

\section{Conservation}

In the past Brooke Bond Tanzania has integrated natural forest protection with its tea plantations and the boundary of the Mufindi estate is marked on the northern edge by the limit of moist forest against cultivation. Recently the company has joined Unilever Plantations International and has brought its environmental policy in line with Unilever's Ecological Charter by issuing a standing order on environmental protection. In recognizing the need to combine commercial objectives with safeguarding the environment, the Ecological Charter aims to use environmental resources in an ecologically sustainable manner and contains the following specific points relating to moist forest:

* primary rain forest will not be destroyed to plant crops;

* areas of unique scientific interest or habitats important for endangered plant or animal species will not be developed;

* environmental impact assessments will be undertaken for any proposed new development.

The area downstream of Luisenga dam wall is of unique scientific interest and so Brooke Bond Tanzania has created a nature reserve on its land there with the specific instructions: 
'There must be no cultivation, or felling of any indigenous tree within $100 \mathrm{~m}$ of the river (Luisenga), within the Company boundary. As far as possible exotic vegetation should be removed (e.g. volunteer pines).'

Some 10,000 ha of the 17,000-ha Mufindi estate of Brooke Bond Tanzania on the southern Uzungwa escarpment is moist forest, and it is hoped that the company will have a continued commitment to forest conservation. Despite the relatively small size of the Luisenga Nature Reserve, its protection is an important step in recognizing the value of habitat patches in conserving the endemic rich flora and fauna of eastern Tanzania.

\section{Acknowledgments}

We gratefully acknowledge the Tanzania Commission for Science and Technology for permission to conduct research in Tanzania. Brooke Bond Tanzania, especially the Chairman, Mr M. S. Keeley, and Estates Director, Mr T. C. E. Congdon, for their kind hospitality. The World Wildlife Fund, National Geographical Society, Wildlife Conservation International, Chapman Fund for the American Museum of Natural History and Mr J. S. Mcllhenny provided funding during the period in which field observations were made. Mr T. C. E. Congdon kindly provided information on the butterflies of Luisenga.

\section{References}

Collar, N. J. and Stuart, S. N. 1985. Threatened Birds of Africa and Related Islands: The ICBP/IUCN Red Data Book. Cambridge, International Council for Bird Preservation and International Union for Conservation of Nature and Natural Resources, Cambridge, UK.
Lovett, J. C. 1985. Moist forests of eastern Tanzania. Swara, 8 (5), 8-9.

Lovett, J.C. 1988a. Practical aspects of moist forest conservation in Tanzania. Monogr. Syst. Bot. Missouri Bot. Gard. 25, 491-496.

Lovett, J. C. 1988b. Endemism and affinities of the Tanzanian montane forest flora. Monogr. Syst. Bot. Missouri Bot. Gard. 25, 591-598.

Lovett, J. C. 1989. Notes on the forest at Luisenga stream, Mufindi, Tanzania. East African Natural History Society Bulletin, 19 (4), 54-55.

Lovett, J.C. 1990. Classification and status of the moist forests of Tanzania. Mitt. Inst. Allg. Bot. Hamburg, 23a, 287-300.

Lovett, J.C. and Norton, G.W. 1989. Afromontane rainforest on Malundwe Hill in Mikumi National Park, Tanzania. Biol. Conserv. 48, 13-19.

Polhill, R.M. 1989. East Africa. In: Floristic Inventory of Tropical Countries (eds D. G. Campbell and D. Hammond), pp. 219-231. New York Botanical Garden.

Redhead, J.F. 1981. The Mazumbai Forest: an island of lower montane rainforest in the West Usambaras. Afr. J. Ecol. 19, 195-199.

Rodgers, W.A and Homewood, K.M. 1982. Biological values and conservation prospects for the forests and primate populations of the Uzungwa mountains. Biol. Conserv. 24, 285-304.

Stuart, S.N. and Jensen, F.P. 1981. Further range extensions and other notable records of forest birds from Tanzania. Scopus, 5, 106-115.

Jon C. Lovett, Department of Botany, University of Dar es Salaam, PO Box 35060, Dar es Salaam, Tanzania; and Missouri Botanical Garden, PO Box 299, St Louis, MO 63166-0299, USA.

David C. Moyer, Museum of Natural Science and Department of Zoology and Physiology, 119 Foster Hall, Louisiana St University, Baton Rouge, LA 70803-3216, USA; and PO Box 2339, Mbeya, Tanzania. 